ADVANCED OPTICAL

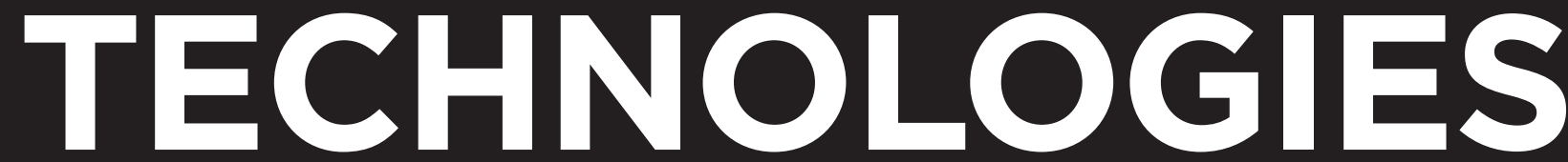

TOPICAL ISSUE

\title{
OPTICS FOR MATERIAL PROCESSING
}

\section{GUEST EDITORS}

Koji Sugioka

Stefan Kaierle

\section{EDITOR-IN-CHIEF}

Michael Pfeffer
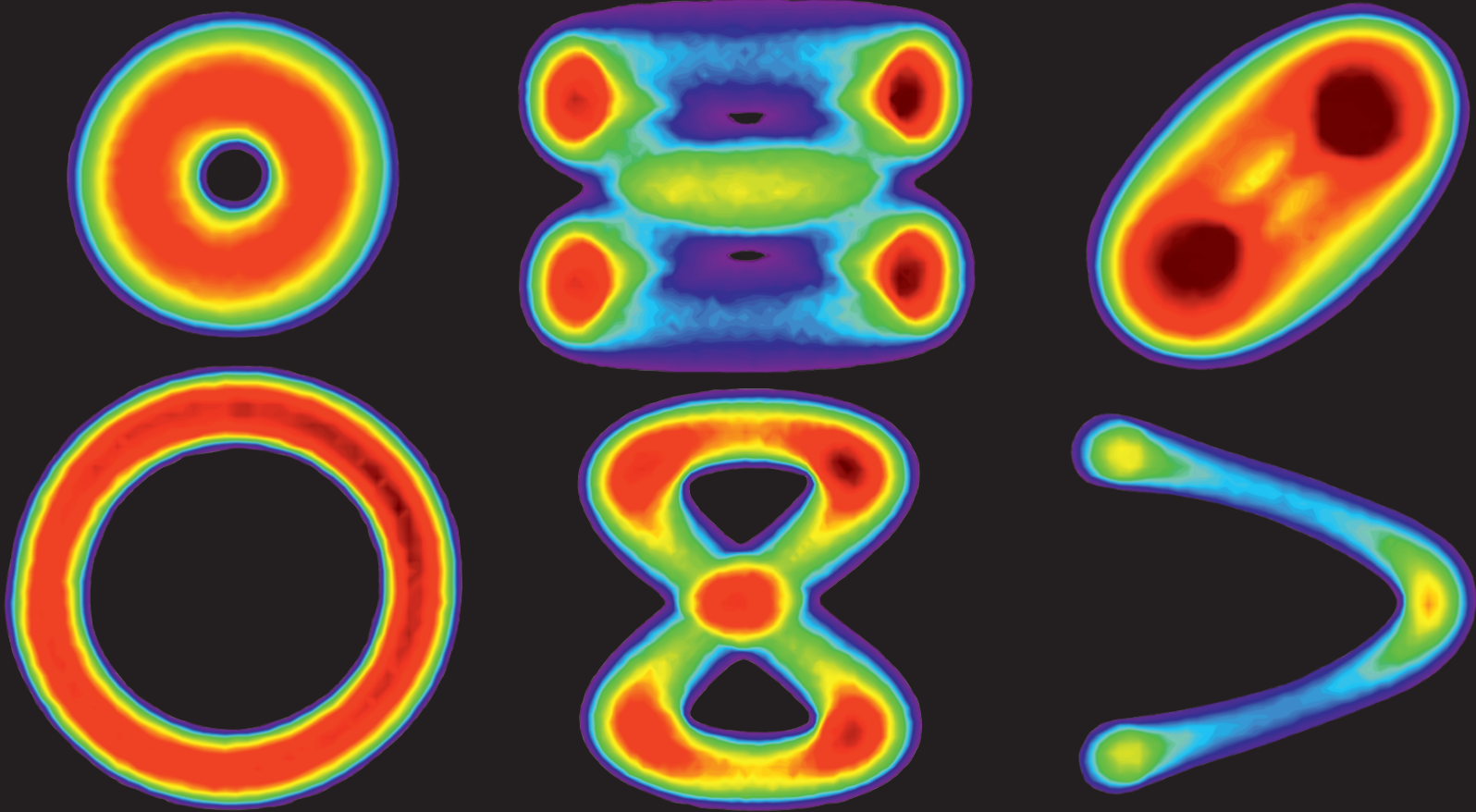

THOSS MEDIA

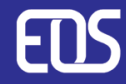




\section{ADVANCED OPTICAL TECHNOLOGIES}

EDITOR-IN-CHIEF

Michael Pfeffer, Weingarten, Germany

University of Applied Sciences Ravensburg-Weingarten, Germany

EDITORIAL BOARD

Stefan Bäumer, TNO Delft, Netherlands

Jan Burke, Fraunhofer IOSB, Germany

Andreas Erdmann, Fraunhofer IISB, Germany

Donis Flagello, Nikon RCA, USA

Michael Golub, Tel Aviv University, Israel

Norbert Kaiser, Fraunhofer IOF, Germany

Yanqiu Li, Beijing Institute of Technology, China

Irina Livshits, St. Petersburg National Research University, Russia

Peter Loosen, Fraunhofer ILT, Germany

Angus Macleod, Thin Film Center Inc., USA

Douglas McCarter, McCarter Machine Inc., USA

Andrew Rakich, ESO, Germany

Peter Seitz, University of Neuchâtel, Switzerland

Stefan Sinzinger, Technical University Ilmenau, Germany

Guohai Situ, Shanghai Institute of Optics and Fine Mechanics, China

Kimio Tatsuno, OITDA, Tokyo, Japan

Hugo Thienpont, Vrije Universiteit Brussel, Belgium

Michael Totzeck, Carl Zeiss AG, Germany

Wilhelm Ulrich, Carl Zeiss AG, Germany

Hexin Wang, Carl Zeiss Shanghai Co. Ltd., China

MANAGING EDITOR

Holger Kleessen, De Gruyter, Berlin, Germany

FOUNDING PUBLISHER

Andreas Thoss, THOSS Media GmbH, Berlin, Germany 
The publisher, together with the authors and editors, has taken great pains to ensure that all information presented in this work (programs, applications, amounts, dosages, etc.) reflects the standard of knowledge at the time of publication. Despite careful manuscript preparation and proof correction, errors can nevertheless occur. Authors, editors and publisher disclaim all responsibility for any errors or omissions of liability for the results obtained from use of the information, or parts thereof, contained in this work.

The citation of registered names, trade names, trademarks, etc. in this work does not imply, even in the absence of a specific statement, that such names are exempt from laws and regulations protecting trademarks etc. and therefore free for general use.

ISSN 2193-8576 · e-ISSN 2193-8584

All information regarding notes for contributors, subscriptions, Open access, back volumes and orders is available online at www.degruyter.com/biomat

EDITOR-IN-CHIEF Michael Pfeffer, Weingarten, Germany, University of Applied Sciences Ravensburg-Weingarten, Germany, Hochschule Ravensburg-Weingarten, Doggenriedstrasse, Postfach 1261, 88241 Weingarten, Germany, Tel.: +49 (0)751 501 9539 , Fax: +49 (0)751 501 9874, Email: michael.pfeffer@hs-weingarten.de

MANAGING EDITOR Holger Kleessen, De Gruyter, Genthiner Straße 13, 10785 Berlin, Germany, Tel.: +49 (0)30 260 05-348, Fax: +49 (0)30 260 05-250, Email: holger.kleessen@degruyter.com

FOUNDING PUBLISHER Andreas Thoss, THOSS Media GmbH, Wolfshagener Str. 56, 13187 Berlin, Germany, Email: th@thoss-media.com

RESPONSIBLE FOR ADVERTISEMENTS Claudia Neumann, De Gruyter, Genthiner Straße 13, 10785 Berlin, Germany. Tel.: +49 (0)30 260 05-226, Fax: +49 (0)30 260 05-322, Email: anzeigen@ degruyter.com

(C) 2016 Walter de Gruyter GmbH, Berlin/Boston and THOSS Media GmbH

TYPESETTING Compuscript Ltd., Shannon, Ireland

PRINTING Franz X. Stückle Druck und Verlag e.K., Ettenheim

Printed in Germany

Cover image: Beam measurement of different Lissajous figures for the laser material processing (Copyright: Fraunhofer IWS).

See also article "Transient beam oscillation with a highly dynamic scanner for laser beam fusion cutting" by C. Goppold et al. on page 61

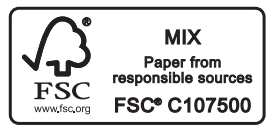

Offenlegung der Inhaber und Beteiligungsverhältnisse gem. § 7a Abs. 1 Ziff. 1, Abs. 2 Ziff. 3 des Berliner Pressegesetzes: Die Gesellschafter der Walter de Gruyter GmbH sind: Clara Cram Stiftung, Berlin; Cram, Gisela, Rentnerin, Berlin; Cram, Dr. Georg-Martin, Unternehmens-Systemberater, Stadtbergen; Cram, Maike, Berlin; Cram, Jens, Mannheim; Cram-Heydrich, Ingrid, Betriebsleiterin, Tuxpan / Michoacan (Mexiko); Cram-Heydrich, Sabina, Mexico, DF (Mexiko); Cram, Silke, Wissenschaftlerin, Mexico DF (Mexiko); Cram, Björn, Aachen; Cram, Ella Anita, Rentnerin, Berlin; Cram, Berit, Greifswald; Cram-Gomez, Susanne, Mexico DF (Mexiko); Cram-Heydrich, Walter, Mexico DF (Mexico); Cram-Heydrich, Kurt, Angestellter, Mexico DF (Mexico); Duvenbeck, Brigitta, Oberstudienrätin i.R., Bad Homburg; Gädeke, Gudula, M.A., Atemtherapeutin/Lehrerin, Tübingen; Gädeke, Martin, Einzelunternehmer, Würzburg; Lubasch, Dr. Annette, Ärztin, Berlin; Schütz, Dr. Christa, Ärztin, Mannheim; Schütz, Sonja, Berlin; Schütz, Juliane, Berlin; Schütz, Antje, Berlin; Schütz, Valentin, Berlin; Seils, Dorothee, Apothekerin, Stuttgart; Seils, Gabriele, Journalistin, Berlin; Seils, Dr. Clara-Eugenie, Oberstudienrätin i.R., Reppenstedt; Seils, Christoph, Journalist, Berlin; Siebert, John-Walter, Pfarrer, Oberstenfeld; Walter de Gruyter Stiftung, Berlin. 


\section{Content}

\section{Editorial}

Andreas Thoss and Michael Pfeffer

Reviewer recognition and new plans for $2016-1$

\section{Community}

Elina Koistinen

News from the European Optical Society -5

Conference Notes -7

Conference Calendar — 11

\section{Topical issue: Optics for material processing}

\section{Editorial}

Koji Sugioka and Stefan Kaierle

Optics for material processing -15

\section{Review Articles}

Mitsuhiro Terakawa and Nikolay N. Nedyalkov

Near-field optics for nanoprocessing - 17

Yoshiki Nakata

Interference laser processing -29
Satoshi Hasegawa and Yoshio Hayasaki

Holographic femtosecond laser manipulation for advanced material processing - 39

\section{Research Articles}

Lasse Büsing, Tobias Bonhoff, Lars Behnke, Jochen Stollenwerk and Peter Loosen

Theoretical and experimental analysis of scan angledepending pulse front tilt in optical systems for laser scanners -55

Cindy Goppold, Thomas Pinder and Patrick Herwig Transient beam oscillation with a highly dynamic scanner for laser beam fusion cutting — 61

Oliver Pütsch, Jochen Stollenwerk and Peter Loosen Adaptive optical beam shaping for compensating projection-induced focus deformation -71

Zhaohui Wang, Yang Liao, Peng Wang, Jia Qi, Lingling Qiao, Koji Sugioka and Ya Cheng

Formation of in-volume nanogratings in glass induced by spatiotemporally focused femtosecond laser pulses $-81$

Jose L. Ocaña, R. Jagdheesh and J.J. García-Ballesteros Direct generation of superhydrophobic microstructures in metals by UV laser sources in the nanosecond regime 87 